\title{
Seroprevalence of Rotavirus infection in pig population of Arunachal Pradesh
}

\author{
G. B. Garam, D. P. Bora, B. Borah, M. Bora and S. K. Das \\ Department of Microbiology, College of Veterinary Science, Assam Agricultural University, Khanapara Campus, \\ Guwahati, Assam, India. \\ Corresponding author: D. P. Bora, e-mail: drdpbora@gmail.com, \\ GBG: niyango@gmail.com, BB: borah.drbiswajyoti@gmail.com, MB: mousumeebora11@gmail.com, \\ SKD: drskdas53@gmail.com \\ Received: 30-08-2016, Accepted: 24-10-2016, Published online: 27-11-2016
}

doi: 10.14202/vetworld.2016.1300-1304 How to cite this article: Garam GB, Bora DP, Borah B, Bora M, Das SK (2016) Seroprevalence of Rotavirus infection in pig population of Arunachal Pradesh, Veterinary World, 9(11): 1300-1304.

\begin{abstract}
Aim: This study was conducted to find out the seroprevalence of Rotavirus(RV) infection among the pig population of Arunachal Pradesh.

Materials and Methods: Serums samples were collected from piglets of age ranging from 1 week to 6 months and the sows associated with the piglets that were reared under organized and unorganized system of management in six different districts of Arunachal Pradesh. The prevalence of RV specific antibodies was detected using a polyclonal antibody-based indirect enzyme-linked immunosorbent assay (i-ELISA).
\end{abstract}

Results: The study revealed that out of 394 serum samples, 255 (64.72\%) samples were found to be positive for RV-specific antibody in i-ELISA. Considering the samples from different districts, Papumpare district of Arunachal Pradesh showed highest numbers of seropositive animals (68.75\%) followed by upper Subansiri (64.91\%) while West Siang district showed lowest positivity rate $(61.22 \%)$.

Conclusion: As considerable seropositivity was recorded among pig population of Arunachal Pradesh in this study, there is urgent need to establish high-impact and cost-effective public health intervention tools, key among them being the introduction of strict hygiene practice and RV vaccination program, to greatly reduce the number of deaths due to diarrheal diseases. To the authors' knowledge, this is the first report on the prevalence of RV infection from pigs of Arunachal Pradesh.

Keywords: antibody, Arunachal Pradesh, pig population, Rotavirus, seropositive.

\section{Introduction}

Rotavirus (RV) infection is the leading cause of moderate to severe acute diarrheal disease in young animals [1]. Since its discovery in 1973, RV has been established as the most common cause of acute viral gastroenteritis among human infants and the neonates of most farm animal species worldwide [2,3]. In piglets, $25-30 \%$ mortality is seen during the preweaning period $[4,5]$. Among infectious agents associated with neonatal enteric disease, RV, Coronavirus, Cryptosporidium, and Escherichia coli collectively are responsible for $75-95 \%$ of infection in which RV alone accounts for about $27-36 \%$ [2]. RV belongs to the genus RV under the family Reoviridae[6]. They are nonenveloped, icosahedral particles consisting of eleven segments of double-stranded RNA enclosed in a triple-layered protein capsid [7]. RVs are classified into G-type and P-type based on the VP7 and VP4 structural genes, respectively [8]. RV is highly

Copyright: Garam, et al. Open Access. This article is distributed under the terms of the Creative Commons Attribution 4.0 International License (http://creativecommons.org/licenses/by/4.0/), which permits unrestricted use, distribution, and reproduction in any medium, provided you give appropriate credit to the original author(s) and the source, provide a link to the Creative Commons license, and indicate if changes were made. The Creative Commons Public Domain Dedication waiver (http://creativecommons.org/ publicdomain/zero/1.0/) applies to the data made available in this article, unless otherwise stated. infectious and may be transmitted via the fecal-oral route and in respiratory droplets $[9,10]$. Infected viruses preferentially multiply in the intestinal epithelia and cause extensive damage to the enterocytes. This results in malabsorption leading severe to acute diarrhea [11].

Arunachal Pradesh, a North Eastern state of India, is a tribal state where there is no any taboo attached to the farming of pigs. Almost all rural household has minimum of one to two or more pigs in their backyard [12]. Pig meat (pork) is very popular among all the tribes of the state. Despite having enormous potential of pig farming in Arunachal Pradesh, due to lack of proper technical knowledge and guidance most of the pig farmers suffers heavy loss due to various kinds of diseases, of which neonatal diarrhea caused by RV is one of the most important diseases in piglets. The prevalence of RV infections in animals has been well documented from different parts of India $[5,13,14]$. However, no data on distribution of RV among pig population of Arunachal are available as no systematic study has been carried out so far. Studies conducted in Assam, a neighboring state of Arunachal Pradesh, have clearly indicated the presence of RV among pig population of the state $[4,15]$. In Assam, the overall prevalence of RV was found to be $41.5 \%$ where maximum numbers of positive cases were found in piglets $(46.3 \%)$ followed by human $(40 \%)$ and cattle 
(37.1\%) [16]. To protect and reduce the prevalence of the disease, epidemiological studies in Arunachal Pradesh are of utmost importance besides developing technologies for the virus isolation, identification and above all molecular characterization of the virus for future vaccine strategy.

This study was conducted to determine the seroprevalence of RV infection in pig population of Arunachal Pradesh, with a view to have some baseline data to formulate control measures.

\section{Materials and Methods}

Ethical approval

Ethical approval for the study was obtained from IAEC, Assam Agricultural University (AAU), Khanapara campus vide approval No.770/ac/CPCSEA/ FVSc/AAU/IAEC/14-15/263 dtd. 20.6.2014.

\section{Farms and animals}

The study was conducted in six districts of Arunachal Pradesh, viz., lower Subansiri, upper Subansiri, East Siang, West Siang, Papumpare, and Lohitwhere pig farming is commonly practiced and was accessible during the study period. The study area with the districts is depicted in Figure-1. The pig population in this area were both organized and unorganized farming. In organized farms, animals were maintained mostly on concrete floors while wooded floors are used in unorganized farms. Further, in organized farms, animals were reared following modern scientific managemental practices such as regular deworming, proper vaccination, etc. In unorganized farms, such practices were not followed. The piglets (2-4 months age) and corresponding sows (mothers') were targeted for studying the RV prevalence.
The serum samples were collected through the active participation of farmers and veterinarians working in the different location of Arunachal Pradesh both from organized and unorganized pig farms.

\section{Serum sample}

Blood samples were collected from piglets having suspected RV-induced diarrheaand associated sows. The samples were obtained from the ear vein or cranial vena cava, and serum was separated by centrifugation (SIGMA, Model 3K30, UK). The samples were labeled properly, transported in ice-box to the laboratory and stored at $-20^{\circ} \mathrm{C}$ for further use. A total of 394 numbers of serum samples were collected from the pig population of six districts of Arunachal Pradesh.

\section{Detection of anti-RV antibody in serum}

Anti-RV antibodies in collected serum samples were detected using an indirect-enzyme-linked immunosorbent assay (i-ELISA) as per method described byHohdatsu et al. [17].

\section{Viral antigen}

Standard Group A RV maintained in the Department of Microbiology, College of Veterinary Science, AAU, Khanapara, Guwahati was used as coating antigen in the i-ELISA.

\section{i-ELISA}

Antibodies to RV in the serum sample were detected and titrated by i-ELISA as per the method of Hohdatsu et al. [18]. Revalidation of the test was done using standard RV antigen and pig anti-RV antibody. The standard RV antigen was used as the coating antigen. Freeze-dried virus was reconstituted in $0.5 \mathrm{ml}$ of distilled water. The working virus dilution was

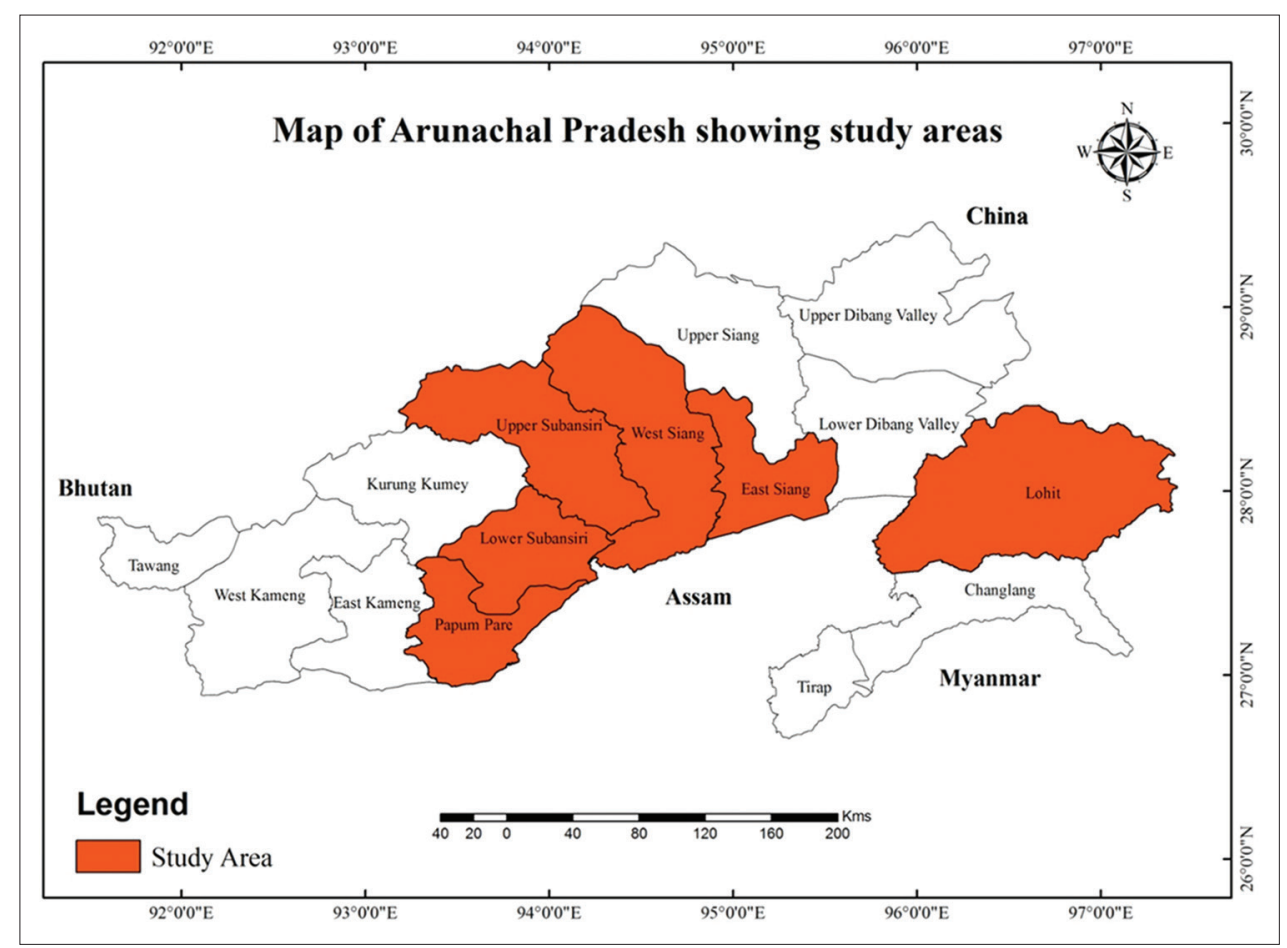

Figure-1: Map of Arunachal Pradesh showing the study areas. [Source: DIVA-GIS programme, URL: www.diva-gis.org]. 
determined following chequerboard titration technique, and the virus titer 1:100 was used as coating antigen in the test.

The test was performed in flat bottom, 96 well microtiter plates (Nunc). The wells were coated with $50 \mu 1$ of 1:100 dilution of RV antigen in carbonated-bicarbonate buffer ( $\mathrm{pH} 9.6)$ and incubated overnight at $4^{\circ} \mathrm{C}$. The plates were washed 4-5 times with Tweenphosphate buffered saline (PBS-T) and two-fold serial dilution of the serum sample was done with initial dilution of 1:10 in blocking buffer containing 5\% lactalbuminhydrolysate in $0.5 \mathrm{M}$ PBS-T.Plates were incubated at $37^{\circ} \mathrm{C}$ for $1 \mathrm{~h}$. The plate was washed again as before. Rabbit anti-swine HRPO conjugate (1:1000, DAKO, Denmark) was added in $50 \mu 1$ volume to all the wells and incubated at $37^{\circ} \mathrm{C}$ for $1 \mathrm{~h}$. Washing was repeated as before. To visualize the amounts of bound conjugate, $50 \mu \mathrm{l}$ of freshly prepared substrate $\left(\mathrm{H}_{2} \mathrm{O}_{2}\right)$ and chromogen (OPD, Sigma) mixture was added to the wells and allowed to react for $15 \mathrm{~min}$. Reaction was stopped by adding $50 \mu \mathrm{l}$ of $1 \mathrm{M} \mathrm{H}_{2} \mathrm{SO}_{4}$ to the wells. The cut-off OD value (OD of positive - OD of negative control) $\geq 0.1$ was considered as positive, and the highest dilution of serum showing positive result was taken as antibody titer of the serum sample. Serum of colostrum deprived piglet was used as negative control in the test.

\section{Results}

Serum samples collected both from piglets $(n=318)$ and sows $(n=78)$ were tested for the presence of anti-RV specific antibody by i-ELISA (Table-1). Out of 394 serum samples, 255 (64.72\%) were found positive for RV antibodies. Considering the age groups, the highest prevalence of RV-specific antibodies (69.23\%) was found in adult animals (sows).Considering the samples from different districts, Papumpare district of Arunachal Pradesh showed highest numbers of seropositive animals $(68.75 \%)$ followed by upper Subansiri (64.91\%) while West Siang district showed lowest positivity rate $(61.22 \%)$. Details of the result are presented graphically in Figure-2.

\section{Discussion}

$\mathrm{RV}$ infection is known to be the major cause of enteritis and diarrhea in neonates of most animal species including human infants [14]. However, infection with RV in animal population in a particular area may vary depending on the management practices and the type of farming $[1,2]$. Serological surveys carried out in various countries showed that $70-100 \%$ adult pigs were seropositive for swine Group A, B and C RV [18,19]. Arunachal Pradesh, a North Eastern state of India, has substantial population of pigs throughout the districts under study [20]. However, there is no data available on the prevalence of RV infection from pig population of Arunachal Pradesh. Results of the present serological study carried out in pigs of Arunachal Pradesh have shown that RV specific antibodies were prevalent in $64.72 \%$ of pigs. Higher prevalence of RV and transmissible gastroenteritis virus antibodies in intensive pig breeding farms was reported by various workers $[21,22]$. Further reports of RV prevalence among pig population of Assam, a neighboring state of Arunachal Pradesh are available [23].

Considering the age groups, the highest prevalence of RV-specific antibodies (69.23\%) was found in adult animals (sows). This is in agreement with the findings of earlier study carried out by Nath[22]. Higher prevalence of RV antibodies in adult pigs might be due to repeated exposure to RV infection at different stages of their life. Highest seroconversion rate (up to 1:640) recorded in adult pigs in the present study also supported this view. In piglets also, a highseropositivity (63.20\%) for RV was detected in the present study. In preweaned pigs, RV specific antibodies were recorded up to $72.5 \%$ and piglets also possessed comparatively higher

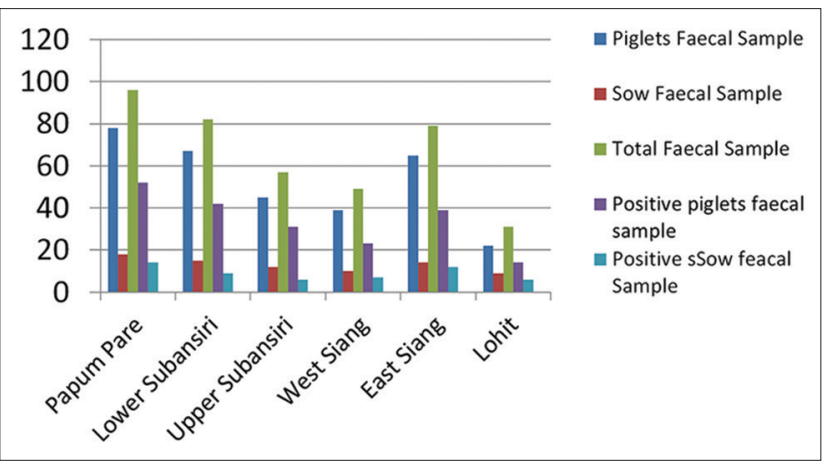

Figure-2: Percent prevalence of rotavirus-specific antibodies in different districts of Arunachal Pradesh.

Table-1: Prevalence of RV-specific antibodies in the serum sample of piglets and sows.

\begin{tabular}{|c|c|c|c|c|c|c|}
\hline \multirow[t]{2}{*}{ Districts } & \multicolumn{2}{|c|}{ Number of serum sample } & \multirow[t]{2}{*}{ Total } & \multicolumn{2}{|c|}{ Number of positive } & \multirow[t]{2}{*}{ Positive (\%) } \\
\hline & Piglets & Sows & & Piglets & Sow & \\
\hline Papum Pare & 78 & 18 & 96 & 52 & 14 & $66(68.75)$ \\
\hline Lower Subansiri & 67 & 15 & 82 & 42 & 9 & $51(62.19)$ \\
\hline Upper Subansiri & 45 & 12 & 57 & 31 & 6 & $37(64.91)$ \\
\hline West Siang & 39 & 10 & 49 & 23 & 7 & $30(61.22)$ \\
\hline East Siang & 65 & 14 & 79 & 39 & 12 & $51(64.55)$ \\
\hline Lohit & 22 & 9 & 31 & 14 & 6 & $20(64.51)$ \\
\hline Overall & 318 & 78 & 394 & 201 & 54 & $255 / 394(64.72)$ \\
\hline
\end{tabular}

$\mathrm{RV}=$ Rotavirus 
antibody titer (up to 1:160). High percentage of seropositive clearly indicated that piglets acquire RV specific antibody via colostrum. These findings are in accordance with that of Hess and Bachmann [24]. They also reported a high percentage of RV seropositivity in piglets, which was due to colostralantibody. Considering the samples from different districts, Papumpare district of Arunachal Pradesh showed highest numbers of seropositive animals (68.75\%) followed by upper Subansiri (64.91\%) while West Siang district showed lowest positivity rate $(61.22 \%)$. Higher seropositivity in the said districts may be due to the more pig population density in these districts in comparison to the other districts of Arunachal Pradesh [20] and the unorganized type of farming followed by the farmers as reported by earlier worker [22].

\section{Conclusion}

This study confirms the prevalence of RV infection among the pig population of Arunachal Pradesh. However, further studies are needed to elucidate the transmission, epidemiology, and characterization of the prevalent RV in the pig population of Arunachal Pradesh.Furthermore, there is urgent need to establish high-impact and cost-effective public health intervention tools, key among them being the introduction of strict hygiene practice and $R V$ vaccination program, to greatly reduce the number of deaths due to diarrheal diseases.

\section{Authors' Contributions}

This study was a part of GBG's research work during his M.V.Sc. program. GBG carried out the experiment. DPB and SKD designed the experiment and provided necessary guidelines. $\mathrm{MB}$ and $\mathrm{BB}$ assisted in laboratory works. DPB drafted the final manuscript. All authors have read and approved the final manuscript.

\section{Acknowledgments}

The authors would like to thank the Department of Biotechnology, Government of India, for providing financial help to carry out the research under DBT twinning project on"Development of improved diagnostics with monitoring and characterization of viral and bacterial pathogens associated with piglet diarrhea in North-eastern region of India" [vide grant no. BT/168/NE/TBP/2011] to carry out the research work. The help received from the field veterinarians of Government of Arunachal Pradesh during sample collection and Ms. Giti Deka, Junior Research Fellow, Department of Microbiology in the preparation of the manuscript is duly acknowledged.

\section{Competing Interests} interests.

\section{References}

1. Miyazaki, A., Kuga, K., Suzuki, T., Kohmoto, M., Katsuda, K. and Tsunemitsu, H. (2011) Genetic diversity of group A rotaviruses associated with repeated outbreaks of diarrhora in a furrow-to-finish farm: Identification of a porcine Rotavirus strain bearing novel VP7 genotype, G26. Vet. Res., 42: 112.

2. Dhama, K., Chauhan, R.S., Mahendran, M. and Malik, S.S.V. (2009) Rotavirus diarrhea in bovines and other domestic animals. Vet. Res. Commun., 33(1): 1-23.

3. Martella, V., Banyai, K., Matthijnssens, J., Buonavoglia, C. and Ciarlet, M. (2010) Zoonotic aspects of Rotaviruses. Vet. Microbiol., 140: 246-255.

4. Bora, D.P., Barman, N.N. and Bhattacharya, D.K. (2007) Isolation of Rotavirus in MA 104 cell line from diarrhoeic piglets of Assam. Indian J. Virol., 18(1): 40-43.

5. Malik, Y.P.S., Kumar, N., Sharma, K., Bora, D.P. and Dutta, T.K. (2014) Rotavirus diarrhea in piglets: A review on epidemiology, genetic diversity and zoonotic risks. Indian J. Anim. Sci., 84(10): 1035-1042.

6. Li, Z., Baker, M.L., Jiang, W., Estes, M.K. and Prasad, B.V. (2009) Rotavirus architecture at subnanometerresulation. $J$. Virol., 83(4): 1754-1766.

7. Ciarlet, M., Gilger, M.A., Barone, C., McArthur, M., Estes, M.K. and Conner, M.E. (1999) Rotavirus disease, but not infection and development of intestinal histopathological lesions is age restricted in rabbits. Virology, 251: 343-360.

8. Papp, H., Laszlo, B., Jakab, F., Ganesh, B., De Grazia, S., Matthijnssens, J.,Ciarlet, M., Martella, V. and Banyai, K. (2013) Review of Rotavirus strains reported in swine and cattle. Vet. Microbiol., 165: 190-199.

9. Fragoso, M., Kumar, A. and Murray, D.L. (1986) Rotavirus in nasopharyngeal secretions of children with upper respiratory tract infections. Diagn. Microbiol. Infect. Dis., 4: 87-88

10. Ansari, S.A., Springthorpe, V.S. and Sattar, S.A. (1991) Survival and vehicular spread of human Rotaviruses: Possible relation to seasonality of outbreaks. Rev. Infect. Dis., 13: 448-461.

11. Lin, C., Chen, S., Liu, S. and Chen, K. (2014) Disease caused by Rotavirus infection. Open Virol. J., 8: 14-19.

12. Tayo, T., Lonhjam, N. and Perme, B. (2011) Protozoan diseases in livestock of Arunachal Pradesh - An overview. Vet. World, 4(7): 332-336.

13. Bora, D.P., Bora, M., Borah, B., Bezborah, B., Sarma, D.K., Malik, Y.P.S. and Dutta, T.K. (2014) Prevalence of Group A Rotaviruses (RVA) in pig population of North East India. $J$. Immunol. Immunopathol.,16(1-2): 53-57.

14. Mondal, A., Sharma, K., Malik, Y.S. and Joardar, S.N. (2013) Detection of group a Rotavirus in faeces of diarrhoeic bovine porcine and human population from Eastern India by reverse transcriptase - Polymerase chain reaction. Adv. Anim. Vet. Sci., 1(1S): 18-19.

15. Barman, N.N., Barman, B., Sharma, D.K. and Pensaert, M.B. (2003) Prevalence of Rotavirus, transmissible gastroenteritis virus and porcine epidemic diarrhea virus antibodies in pigs of Assam. Indian J. Anim. Sci., 73(6): 576-578.

16. Sharma, R., Bora, D.P., Chakraborty, P., Das, S. and Barman, N.N. (2013) Circulation of group A Rotaviruses among neonates of human, cow and pig: Study from Assam, a North Eastern state of India. Indian J. Virol., 24: 250-255.

17. Hohdatsu, T., Eiguchi, Y., Ide, S., Baba, K. and Yamagishi, H. (1987) Evaluation of an enzyme linked immunosorbent assay for the detection of transmissible gastroenteritis virus antibodies. Vet. Microbiol., 13: 93-97.

18. Markowska-Daniel, I., Pejsak, Z. and Winiarezyk, S. (1996) Diagnosis of Rotavirus infection in piglets. Acta Acad. Agric. Tech. Olsten. Vet., 23: 119-134.

19. Bridger, J.C. and Brown, J.F. (1985) Prevalence of antibody 
to typical and atypical rotavirus in pigs. Vet. Rec., 116: 50.

20. State Profile of Arunachal Pradesh Report. (2013-14) Published by MSME Development Institute, Government of India, Itanagar Branch, Arunachal Pradesh.

21. Barman, N.N., Sarma, D.K. and Pensaert, M. (1998) Detection of swine rotavirus and transmissible gastroenteritis virus in piglets with diarrhea by sandwich ELISA. Indian J. Anim. Sci., 68(9): 886-887.

22. Nath, A.J. (2003) Seroprevalence and Faecal Excretion Pattern of Rotavirus in Naturally Infected Pigs. M.V.Sc.
Thesis. Assam Agricultural University, Guwahati, India.

23. Neog, B.K., Barman, N.N., Bora, D.P., Dey, S.C. and Chakraborty, A. (2011) Experimental infection of pigs with group A Rotavirus and enterotoxigenic Escherichia coli in India: Gross, histopathological and immunopathological study. Vet. Ital., 47: 117-128.

24. Hess, R.G. and Bachmann, A. (1998) Distribution of antibodies to rotavirus in serum and lacteal secretions of naturally infected swine and their suckling pigs. Am. J. Vet. Res., 42: $1149-1153$.

$* * * * * * * *$ 